Article

\title{
Tunable Effect of the Calcination of the Silanol Groups of KIT-6 and SBA-15 Mesoporous Materials
}

\author{
Adriano M. Basso ${ }^{1}\left(\mathbb{D}\right.$, Bruna P. Nicola ${ }^{2}$, Katia Bernardo-Gusmão ${ }^{2}$ and Sibele B. C. Pergher ${ }^{1, *(C)}$ \\ 1 Chemistry Institute, Federal University of Rio Grande do Norte, Natal-RN 59078-970, Brazil; \\ adriano.basso@ifrn.edu.br \\ 2 Chemistry Institute, Federal University of Rio Grande do Sul, Porto Alegre-RS 90040-060, Brazil; \\ bruna.pnicola@hotmail.com (B.P.N.); katiabg@iq.ufrgs.br (K.B.-G.) \\ * Correspondence: sibelepergher@gmail.com or sibele.pergher@pesquisador.cnpq.br
}

Received: 19 December 2019; Accepted: 22 January 2020; Published: 2 February 2020

\begin{abstract}
The calcination process is a crucial step during SBA-15 and KIT-6 synthesis. It is used to completely remove the organic template and condense silanol groups, and it allows the determination of the textural and physical properties of these materials, depending on the adopted conditions. Moreover, calcination influences the number of silanols available on the surface of the material. The concentration of silanols is important if these materials were synthesized for use in adsorption or functionalization. To understand and optimize the silanol groups of SBA-15 and KIT-6, in this study, the temperature and time calcination parameters were varied. The experiments were performed at 300,400 , and $500{ }^{\circ} \mathrm{C}$ for 300,400 , and $500 \mathrm{~min}$. The results show that the ideal temperature to preserve the silanol groups is $300^{\circ} \mathrm{C}$, but to optimize the textural properties, it is better to calcine these molecular sieves at $400{ }^{\circ} \mathrm{C}$. A calcination for $10 \mathrm{~h}$ did not give better results than a calcination for $5 \mathrm{~h}$, demonstrating that the former duration is excessive for use.
\end{abstract}

Keywords: mesoporous materials; KIT-6; SBA-15; silanol groups; calcination

\section{Introduction}

According to the IUPAC (International Union of Pure and Applied Chemistry), porous materials can be grouped into three distinct categories according to their porosities [1]. Materials with pores smaller than $2 \mathrm{~nm}$ are classified as microporous, those with pores larger than $50 \mathrm{~nm}$ are called macroporous, and those with intermediate pore sizes are mesoporous [2]. In the early 1990s, Mobil Oil Corporation researchers published the first syntheses of mesoporous materials (M41S), which were manufactured using an alkyltriethylammonium halide as a template in an alkaline medium $[3,4]$. These new compounds presented very characteristic and peculiar properties, such as a high specific surface area (up to $1400 \mathrm{~m}^{2} \mathrm{~g}^{-1}$ ), a pore volume greater than $0.5 \mathrm{~cm}^{3} \mathrm{~g}^{-1}$ and narrowly distributed cylindrical pores $(2-30 \mathrm{~nm})$ [5]. The physicochemical properties of these compounds have been tested and evaluated by many researchers [6-12].

In 1998, the syntheses of a group of mesoporous materials called SBA, using an organic copolymer (mainly PEO-PPO-PEO) as a template in an acid medium, were published $[13,14]$. In this family of compounds, the best known is SBA-15, which is a highly ordered two-dimensional hexagonal (P6mm) thick-walled silica (3 to $6 \mathrm{~nm}$ ) mesostructured material with uniform, large, adjustable pores up to $30 \mathrm{~nm}$ in diameter and high thermal and hydrothermal stability due to the presence of mesoporous interconnected micropores [13]. In 2003, the synthesis of a new mesoporous material called KIT-6 was first published [15]. This material was manufactured in a manner very similar to that used in the production of the SBA-15 but using butanol-1 as a swelling agent. KIT-6 exhibits cubic Ia3d symmetry with excellent thermal/hydrothermal stabilities and consists of two continuous and interpenetrating 
chiral channel systems interconnected in a three-dimensional open cylindrical mesoporous network [16]. It has a wall thickness between 4 and $6 \mathrm{~nm}$ [17], a specific area of up to $800 \mathrm{~m}^{2} \mathrm{~g}^{-1}$, and a high pore volume (up to $1.05 \mathrm{~cm}^{3} \mathrm{~g}^{-1}$ ) with pore diameters in the range of 4 to $12 \mathrm{~nm}$ [15]. The main pores are interconnected with micropores up to $1.8 \mathrm{~nm}$ in diameter at specific points [18,19].

With the discoveries of these two mesoporous nanosilica (MNS) materials, a wide range of possibilities has been opened for the application of both SBA-15 [20-28] and KIT-6 [29-37] in various areas, such as catalysis, adsorption, separation, drug release, optical devices, and sensors. The development of MNS has involved three distinct generations [38]. The first corresponded to the conceptual demonstration of MNS through the discovery of materials such as the M41S and SBA families. The second generation was characterized by the improvement and refinement of the study of these materials in terms of in vitro applications and in situ analysis. Finally, the third and current generation of studies functionalized MNS $[39,40]$. Pure silica mesoporous materials have intrinsic limitations in both functionality and strength, and controlling the pore surface chemistry is critical to improving their applications [12]. The surface functionalization of these mesoporous compounds with organic and inorganic functional groups leads to the formation of materials with new physicochemical properties [41], which can be used in various areas, such as catalysis, adsorption, and separation [42,43].

The formation of the materials SBA-15 and KIT-6 are made by the sol-gel process [44]. This is a traditional methodology based on the hydrolysis and condensation of metal alkoxides (TEOS) to produce colloidal particles (sol) that are converted into a lattice (gel) [45]. The conditions employed directly affect the properties of the materials produced. The most important parameters in the sol-gel process is the type of silanol group, its concentrations, the $\mathrm{pH}$, the solvent, thermic treatment, aging time, and the additives, such as catalysts and co-solvents [45-50].

SBA-15 and KIT-6 pure silica materials contain two basic types of silicon-oxygen groups. The first is siloxanes, and the second is silanol-type hydroxyls that can be divided into three groups, free silanols, vicinal silanols, and geminal silanols [44], as shown in Figure 1.

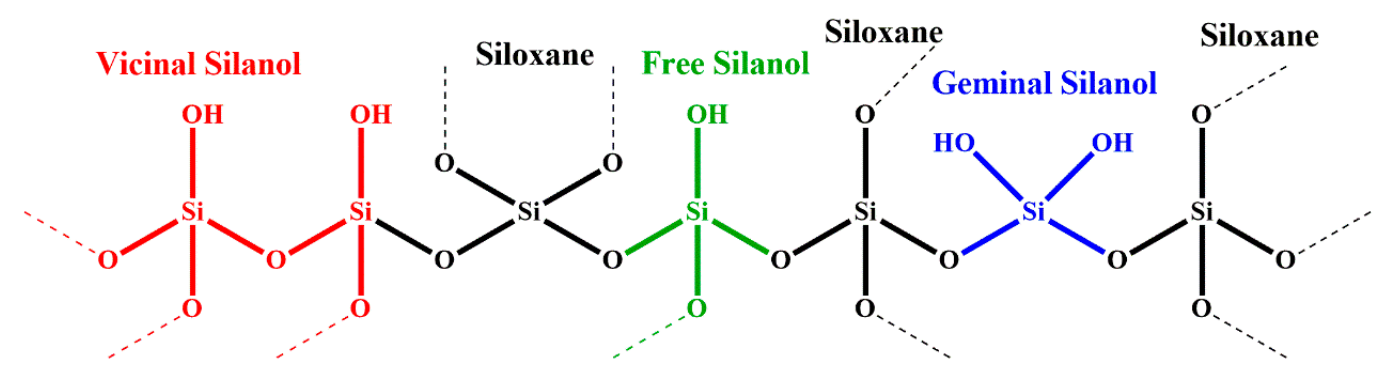

Figure 1. Silicon-oxygen group types present in SBA-15 and KIT-6.

Siloxane groups are more hydrophobic, are the most abundant group, and make up the interior of SBA-15 and KIT-6 MNS. Silanol groups attract the most attention in regard to the functionalization of MNS because hydroxyl groups react more easily with other chemical species [51]. Thus, it is of interest to preserve these silanol groups in the highest concentration possible. For this, it is necessary to use low temperatures in the calcination of MNS, since temperature is the main factor leading to a decrease in the silanol concentration [52]. However, there are boundaries to the temperature used in all SBA-15 and KIT- 6 synthesis processes. The use of a high temperature is necessary for the formation of mesoporous materials, through the condensation of hydroxyls, to form siloxane bonds, but several studies have demonstrated the effects on the quality of the temperature-related MNS formation used during a static hydrothermal synthesis of SBA-15 [53-55] and KIT-6 [5]. Nevertheless, during the calcination process, these bonds are consolidated, giving rise to the desired material when the largest loss of surface silanol groups occurs; however, too great a loss leaves the material unusable for functionalization.

This study thus proposes calcining samples of SBA-15 and KIT- 6 at different temperatures and different calcination times. To determine the efficiency of these thermal processes, the carbon content 
was monitored by thermal analysis, the X-ray diffraction (XRD) patterns of the mesoporous material were evaluated, the textural properties were assessed by $\mathrm{N}_{2}$ sorption, and the availability of silanol and siloxane groups were monitored by nuclear magnetic resonance (NMR) ${ }^{29} \mathrm{Si}\left\{{ }^{1} \mathrm{H}\right\}$ cross-polarization magic-angle spinning (CP-MAS). The choice of these MNS materials was based on two different factors. On the one hand, the SBA-15 is a heavily studied material, with many articles published on its functionalization [25,56-60], and while KIT-6 is a relatively new material, it has already attracted much attention in studies worldwide, with some works about its functionalization [61-68]; on the other hand, the availability of silanol groups in KIT-6 has been less investigated, whereas it has already been reported for SBA-15 [51,56,69-71].

\section{Materials and Methods}

\subsection{Chemicals}

Pluronic P123 triblock copolymer $\left(\mathrm{EO}_{20} \mathrm{PO}_{70} \mathrm{EO}_{20}, \mathrm{Mn}=5800\right.$, Aldrich, St. Louis, MO, USA), tetraethyl orthosilicate (TEOS, Aldrich, 98\%), butanol (Aldrich, 99.4\%), and hydrochloric acid ( $\mathrm{HCl}$, Atrion, $37 \mathrm{wt} \%$ ) were used to synthesize the mesoporous samples.

\subsection{Characterization}

Small-angle X-ray diffraction (XRD) patterns at $2 \theta$ angles from $0.5^{\circ}$ to $5^{\circ}$ were recorded on a Bruker D8 diffractometer using $\mathrm{Cu} \mathrm{K} \alpha$ radiation $(30 \mathrm{kV}, 10 \mathrm{~mA})$. Nitrogen adsorption isotherms were collected by a Micromeritics Tristar II instrument at $-196^{\circ} \mathrm{C}(77 \mathrm{~K})$. The samples were degassed under vacuum at $200{ }^{\circ} \mathrm{C}$ overnight. The Brunauer-Emmett-Teller (BET) method was used to calculate the specific surface area. The total pore volume was determined at a relative pressure $\mathrm{p} / \mathrm{p}^{0}$ of 0.98 . The mesoporous and microporous volumes were obtained using $\alpha$ s-plots methodology. The pore size distribution was determined my means of the Barrett-Joyner-Halenda $(\mathrm{BJH})$ method, using the correction factor proposed in the Villarroel-Barrera-Sapag (VBS) method. The carbon, hydrogen and nitrogen elemental analyses were performed using a Perkin Elmer Series II 2400. The silicon nuclear magnetic resonance $\left({ }^{29} \mathrm{Si}-\mathrm{NMR}\right)$ solid-state spectra were registered on an Agilent DD2 $500 \mathrm{MHz}$ spectrometer. The method utilized was cross-polarization magic-angle spinning (CP-MAS) at a Larmor frequency of $99.3 \mathrm{MHz}$, a pulse duration of $2.9 \mathrm{~ms}$, a relaxation time of $5 \mathrm{~s}$, an acquisition time of $17 \mathrm{~ms}$, and a scan number of 12,000 .

\subsection{Synthesis of $S B A-15$}

This material was prepared by the conventional methodology [72] of dissolving $12.1 \mathrm{~g}$ of P123 in an $\mathrm{HCl}$ solution $\left(450 \mathrm{~mL}, 2.0 \mathrm{~mol} \mathrm{~L}^{-1}\right)$. The system was magnetically stirred at approximately $500 \mathrm{rpm}$ for two hours at $45^{\circ} \mathrm{C}$. When the mixture became a homogeneous solution, $4.3 \mathrm{~g}$ of TEOS was added to the reaction container in a dropwise manner. The system was kept at $45^{\circ} \mathrm{C}$ for $24 \mathrm{~h}$ under stirring. After that, the mixture was transferred to an autoclave, and a hydrothermal treatment was performed for $24 \mathrm{~h}$ at $110^{\circ} \mathrm{C}$. The product obtained was filtered and washed with distilled water to a neutral $\mathrm{pH}$. The material was then dried at $60^{\circ} \mathrm{C}$ for $26 \mathrm{~h}$. The SBA- 15 produced was heat-treated under different conditions.

\subsection{Synthesis of KIT-6}

The production of this mesoporous material was performed using the partitioned cooperative self-assembly (PCSA) methodology [73]. First, $18.6 \mathrm{~g}$ of P123 was dissolved in $669.6 \mathrm{~g}$ of distilled water and $36.8 \mathrm{~g}$ of concentrated $\mathrm{HCl}$. The system was magnetically stirred at approximately $800 \mathrm{rpm}$ at $35{ }^{\circ} \mathrm{C}$ for $90 \mathrm{~min}$. After this period, $18.6 \mathrm{~g}$ of 1-butanol was slowly added. After $60 \mathrm{~min}$ under the same temperature and stirring conditions, $28 \mathrm{~g}$ (70\% equivalent) of TEOS was dropped into the synthesis mixture. After $5 \mathrm{~h}$, the remaining 30\% TEOS (12 g) was added in the same way. The system was continuously agitated at approximately $800 \mathrm{rpm}$ at $35^{\circ} \mathrm{C}$ for $24 \mathrm{~h}$. The material was then transferred to 
a Teflon autoclave and placed in a digester block, where it remained for $24 \mathrm{~h}$ at $100{ }^{\circ} \mathrm{C}$. The formed material was filtered with distilled water to $\mathrm{pH} 7$ and dried for $17 \mathrm{~h}$ at $60^{\circ} \mathrm{C}$.

\subsection{The Methodology of Mesoporous Calcination}

The mesoporous material synthesized was calcined through six different methodologies using a muffle furnace. The sample mass used in each method, as well as the calcination conditions, are detailed in Table 1.

Table 1. Methodologies used for the calcination of SBA-15 and KIT-6 samples.

\begin{tabular}{ccccc}
\hline Method & Temperature $^{\mathbf{1}}\left({ }^{\circ} \mathbf{C}\right)$ & Time (h) & SBA-15 Mass (mg) & KIT-6 Mass (mg) \\
\hline 1 & 300 & 5 & 514 & 519 \\
2 & 300 & 10 & 515 & 516 \\
3 & 400 & 5 & 512 & 556 \\
4 & 400 & 10 & 515 & 516 \\
5 & 500 & 5 & 508 & 514 \\
6 & 500 & 10 & 502 & 503 \\
\hline
\end{tabular}

The samples were identified by utilizing the letter $\mathrm{S}$ to designate SBA-15 and the letter $\mathrm{K}$ to designate KIT-6. The calcination methodology used is indicated by the letter M followed by the method number. For example, the identification code SM5 corresponds to the sample of SBA-15 calcinated according to method number 5 . The number zero indicates that the material was not calcinated.

\section{Results and Discussion}

\subsection{Effect of Calcination Temperature on the Quantity of Polymer}

The effect of calcination on the amount of polymer in the mesoporous material was assessed by measuring the amount of carbon remaining in the material by elemental analysis. The results are shown in Table 2.

Table 2. Residual carbon content in the SBA-15 and KIT-6 samples.

\begin{tabular}{cccc}
\hline Samples & Residual Carbon Content (\%) & Samples & Residual Carbon Content (\%) \\
\hline SM0 & 25.33 & KM0 & 28.86 \\
SM1 & 0.32 & KM1 & 0.42 \\
SM2 & 0.19 & KM2 & 0.30 \\
SM3 & 0.08 & KM3 & 0.09 \\
SM4 & 0.08 & KM4 & 0.09 \\
SM5 & 0.03 & KM5 & 0.09 \\
SM6 & 0.01 & KM6 & 0.07 \\
\hline
\end{tabular}

Both SBA-15 and KIT-6 lose most of their organic templates at $300{ }^{\circ} \mathrm{C}$ in the first two heat treatment methods. After treatment for $5 \mathrm{~h}, 0.32 \%$ and $0.42 \%$ of the carbon remains for SBA- 15 and KIT- 6 , respectively. Upon increasing the treatment time to $10 \mathrm{~h}$, the amount of carbon remaining drops to $0.19 \%$ for SBA- 15 and $0.30 \%$ for KIT-6, indicating that the polymer remains in the mesoporous materials. Previous studies $[51,55,69]$ have shown that, at $200^{\circ} \mathrm{C}$, the polymer decomposes and that, by calcining for $4 \mathrm{~h}$ at $300^{\circ} \mathrm{C}$ or for $4 \mathrm{~h}$ at $350^{\circ} \mathrm{C}$, the polymer is removed; however, to the best of our knowledge, no work has quantified the residual polymer content. When comparing the results obtained at a higher temperature $\left(500{ }^{\circ} \mathrm{C}\right)$ with those obtained at an intermediate temperature $\left(400^{\circ} \mathrm{C}\right)$, the difference in the amount of organic material removed is too small. Another factor is the time at higher temperatures; calcining for $10 \mathrm{~h}$ does not result in substantial benefits in terms of the removal of organic material, since the values of $\% \mathrm{C}$ remaining are identical at $400{ }^{\circ} \mathrm{C}$ and are almost equal at $500{ }^{\circ} \mathrm{C}$ for the two 
mesoporous materials. Nonetheless, at $300{ }^{\circ} \mathrm{C}$, there is a large difference between calcination at 5 and $10 \mathrm{~h}$. The results of this analysis are shown in Figure 2.
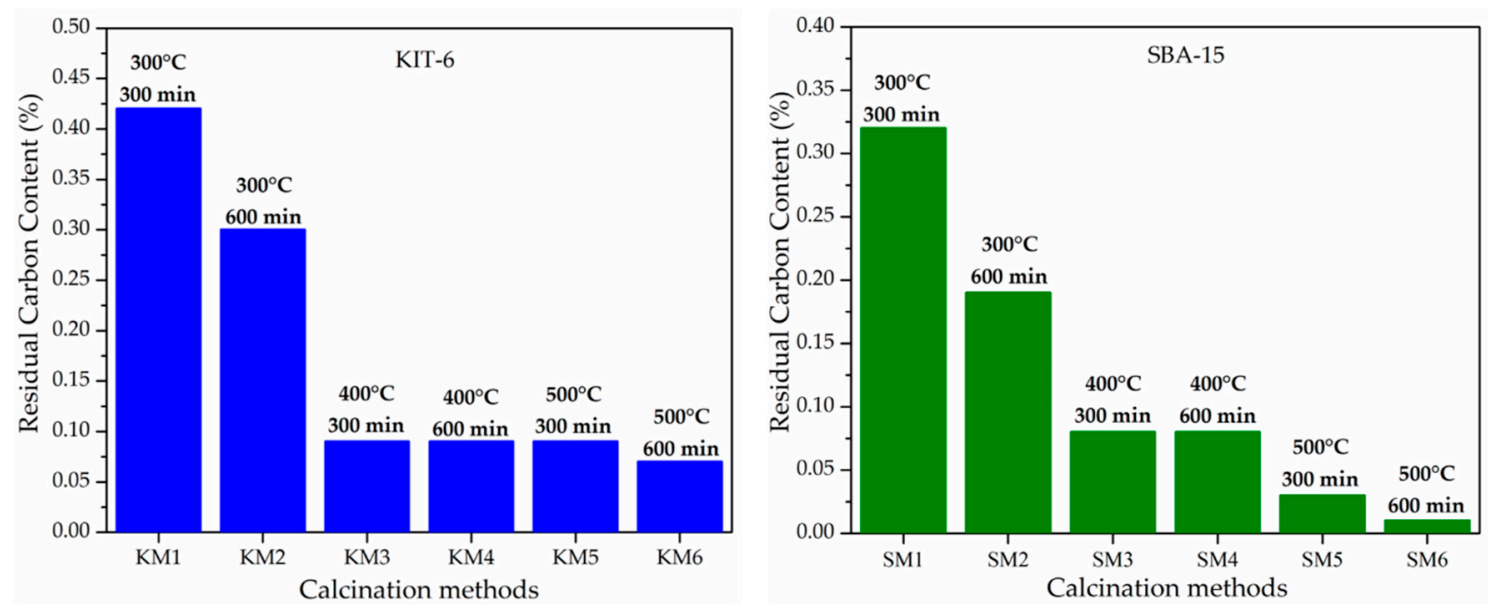

Figure 2. The residual carbon content for KIT-6 and SBA-15 after each calcination method.

\subsection{Effect of Calcination Temperature on the Mesostructure of the MNS}

As already stated, the structure of mesoporous materials was monitored by XRD analysis to determine the effects of calcination temperature. The results are presented in Table 3.

Table 3. Results of the X-ray diffraction (XRD) analyses of the mesoporous nanosilica (MNS) samples.

\begin{tabular}{cccccc}
\hline Samples & $\mathbf{d}_{\mathbf{1 1 0}}(\mathbf{n m})$ & $\mathbf{a}_{\mathbf{0}}(\mathbf{n m})^{\mathbf{1}}$ & Samples & $\mathbf{d}_{\mathbf{2 1 1}}(\mathbf{n m})$ & $\mathbf{a}_{\mathbf{0}}(\mathbf{n m})^{\mathbf{2}}$ \\
\hline SM0 & 11.2 & 13.0 & KM0 & 10.7 & 26.2 \\
SM1 & 10.4 & 12.0 & KM1 & 9.4 & 23.0 \\
SM2 & 10.3 & 11.9 & KM2 & 9.8 & 24.0 \\
SM3 & 10.8 & 12.5 & KM3 & 9.6 & 23.5 \\
SM4 & 10.8 & 12.5 & KM4 & 9.7 & 23.8 \\
SM5 & 10.6 & 12.2 & KM5 & 9.8 & 24.0 \\
SM6 & 10.4 & 12.0 & KM6 & 9.4 & 23.3 \\
1 calculated by the formula [62] $\mathrm{a}_{0}=2 . \mathrm{d}_{100} \cdot 100 . \sqrt{3},{ }^{2}$ calculated by the formula $[66] \mathrm{a}_{0}=\mathrm{d}_{211} \cdot \sqrt{6}$.
\end{tabular}

All XRD diffractograms show the formation of materials with angles of $0.8^{\circ}<2 \theta<2^{\circ}$, characteristic of mesoporous materials, and are displayed in Figure 3. An analysis of Figure 3 shows that, among the calcined samples, all SBA samples have good structural organization except that prepared by Method 1. All KIT-6 samples showed good structural organization, indicating that the different calcination methods had little influence on the mesostructure, as expected [13-15]. Moreover, in all calcinated materials, the pores shrink more than in the noncalcinated materials, but among all calcination methods, there is no linear relationship between pore shrinkage and the calcination temperature. 

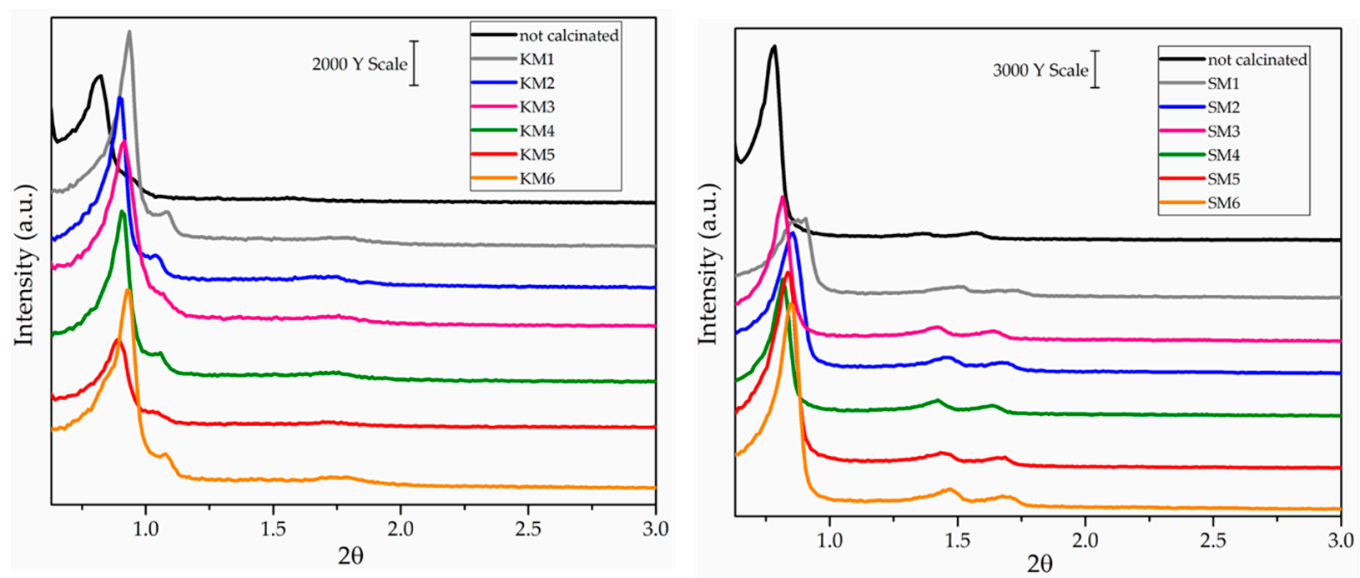

Figure 3. Small-angle XRD pattern of KIT-6 and SBA-15 calcinated under different conditions.

\subsection{Effect of the Calcination Temperature on the Textural Properties of the MNS}

The porosity of calcined MNS materials under different conditions was analyzed by $\mathrm{N}_{2}$ sorption. As expected for these materials, isotherms are type IVa (according to the new IUPAC [74] classification) with type I hysteresis. Figure 4 shows the SBA-15 isotherms, and Figure 5 shows the KIT-6 isotherms. The physical properties taken from these isotherms are presented in Table 4.

Table 4. Physical properties of SBA-15 and KIT-6 samples.

\begin{tabular}{|c|c|c|c|c|c|c|}
\hline Samples & $\begin{array}{c}\mathrm{A}_{\mathrm{BET}} \\
\left(\mathrm{m}^{2} \mathrm{~g}^{-1}\right)\end{array}$ & $\begin{array}{c}V_{T} \\
\left(\mathrm{~cm}^{3} \mathrm{~g}^{-1}\right)\end{array}$ & $\begin{array}{c}\mathrm{V}_{\mathrm{Mi}} \\
\left(\mathrm{cm}^{3} \mathrm{~g}^{-1}\right)\end{array}$ & $\begin{array}{c}V_{M e} \\
\left(\mathrm{~cm}^{3} \mathrm{~g}^{-1}\right)\end{array}$ & $\begin{array}{c}D_{p} \\
(n m)\end{array}$ & $\begin{array}{c}W_{t} \\
(\mathrm{~nm})\end{array}$ \\
\hline SM1 & 572 & 0.78 & 0.02 & 0.76 & 7.5 & 4.5 \\
\hline SM2 & 632 & 0.86 & 0.02 & 0.84 & 7.5 & 4.4 \\
\hline SM3 & 641 & 0.84 & 0.03 & 0.81 & 7.8 & 4.7 \\
\hline SM4 & 1197 & 1.52 & 0.04 & 1.48 & 7.5 & 5.0 \\
\hline SM5 & 1099 & 1.69 & 0.00 & 1.69 & 8.9 & 3.3 \\
\hline SM6 & 770 & 0.98 & 0.06 & 0.92 & 7.8 & 4.2 \\
\hline KM1 & 695 & 0.82 & 0.07 & 0.75 & 7.2 & 15.8 \\
\hline KM2 & 826 & 0.98 & 0.07 & 0.91 & 6.1 & 17.9 \\
\hline KM3 & 905 & 1.07 & 0.07 & 1.00 & 7.5 & 16.0 \\
\hline KM4 & 852 & 1.03 & 0.08 & 0.95 & 7.9 & 15.9 \\
\hline KM5 & 1174 & 1.44 & 0.08 & 1.36 & 7.3 & 16.7 \\
\hline KM6 & 874 & 1.10 & 0.05 & 1.05 & 7.4 & 15.6 \\
\hline
\end{tabular}

$\mathrm{A}_{\mathrm{BET}}$ is the specific area obtained from the Brunauer-Emmett-Teller (BET) method. The $\mathrm{V}_{\mathrm{T}}$ is the total pore volume obtained from a relative pressure $\mathrm{p} / \mathrm{p}^{0}$ equal to 0.98 . The $\mathrm{V}_{\mathrm{Mi}}$ is the microporous volume obtained from the $\alpha$-plots method. The $\mathrm{V}_{\mathrm{Me}}$ is the mesoporous volume obtained from the $\alpha$-plots method. The $\mathrm{D}_{\mathrm{p}}$ is the pore diameter obtained from the Barrett-Joyner-Halenda (BJH) method corrected from the Villarroel-Barrera-Sapag (VBS) method. The $\mathrm{W}_{\mathrm{t}}$ is the wall thickness.

For SBA-15 and KIT-6, the BET area indicates a suitable porosity with material type [13-15]. The samples of SBA-15 presented the maximum value of $A_{B E T}$ upon calcination at $400{ }^{\circ} \mathrm{C}$ for 10 $\mathrm{h}$. Increasing the temperature to $500{ }^{\circ} \mathrm{C}$ for $5 \mathrm{~h}$ decreased the value of $\mathrm{A}_{\mathrm{BET}}$ slightly (from 1197 to $1099 \mathrm{~m}^{2} \mathrm{~g}^{-1}$ ), and maintaining the temperature at $500{ }^{\circ} \mathrm{C}$ but doubling the calcination time to $10 \mathrm{~h}$ considerably decreased the value of the total material area to $770 \mathrm{~m}^{2} \mathrm{~g}^{-1}$. This decrease in the area must be associated with the process of the dehydroxylation of the material, which begins to intensify under these heat treatment conditions. For KIT-6, a calcination at $300{ }^{\circ} \mathrm{C}$ for $5 \mathrm{~h}$ results in the lowest total area value. This is quite reasonable since it is under these conditions that the largest amount of organic material exists, as attested by the results of elemental carbon analysis. The largest BET area was obtained by calcining at $500{ }^{\circ} \mathrm{C}$ for $5 \mathrm{~h}$. When the heat exposure time was increased from 5 to $10 \mathrm{~h}$ without an increase in the temperature, the BET area decreased $\left(1174\right.$ to $\left.874 \mathrm{~m}^{2} \mathrm{~g}^{-1}\right)$. This indicates that 
at temperatures above $500{ }^{\circ} \mathrm{C}$, contraction of the structure begins to occur, indicating a dehydroxylation process of KIT-6 [69].

From the measurements made after the capillary condensation step at the beginning of the isotherm plateau, the total pore volume was determined from the adsorbed nitrogen volume values. Micropore and mesopore volumes were calculated according to reference [75]. Since SBA-15 has hexagonal cells and KIT- 6 has cubic cells, the calculation of the network parameters $\mathrm{a}_{0}$ is different, and consequently, the calculation of the pore wall thickness $\left(\mathrm{W}_{\mathrm{t}}\right)$ will also be performed by two different methods. For the SBA-15 samples, the formula adopted [13] is $W_{t}=a_{0}-D_{p}$, and for the KIT- 6 samples, the thickness is determined by the expression [66] $W_{t}=\frac{a_{0}}{2}-D_{p}$. The pore diameter $\left(D_{p}\right)$ was determined with the adsorption branch by the BJH (Barrett-Joyner-Halenda) method, and the mesoporous correction was done in accordance with to the VBS (Villarroel-Barrera-Sapag) method. This is an improved macroscopic method that modifies the Kelvin equation used in the BJH method and considers the most accepted capillary evaporation and condensation mechanisms for mesoporous materials [76].
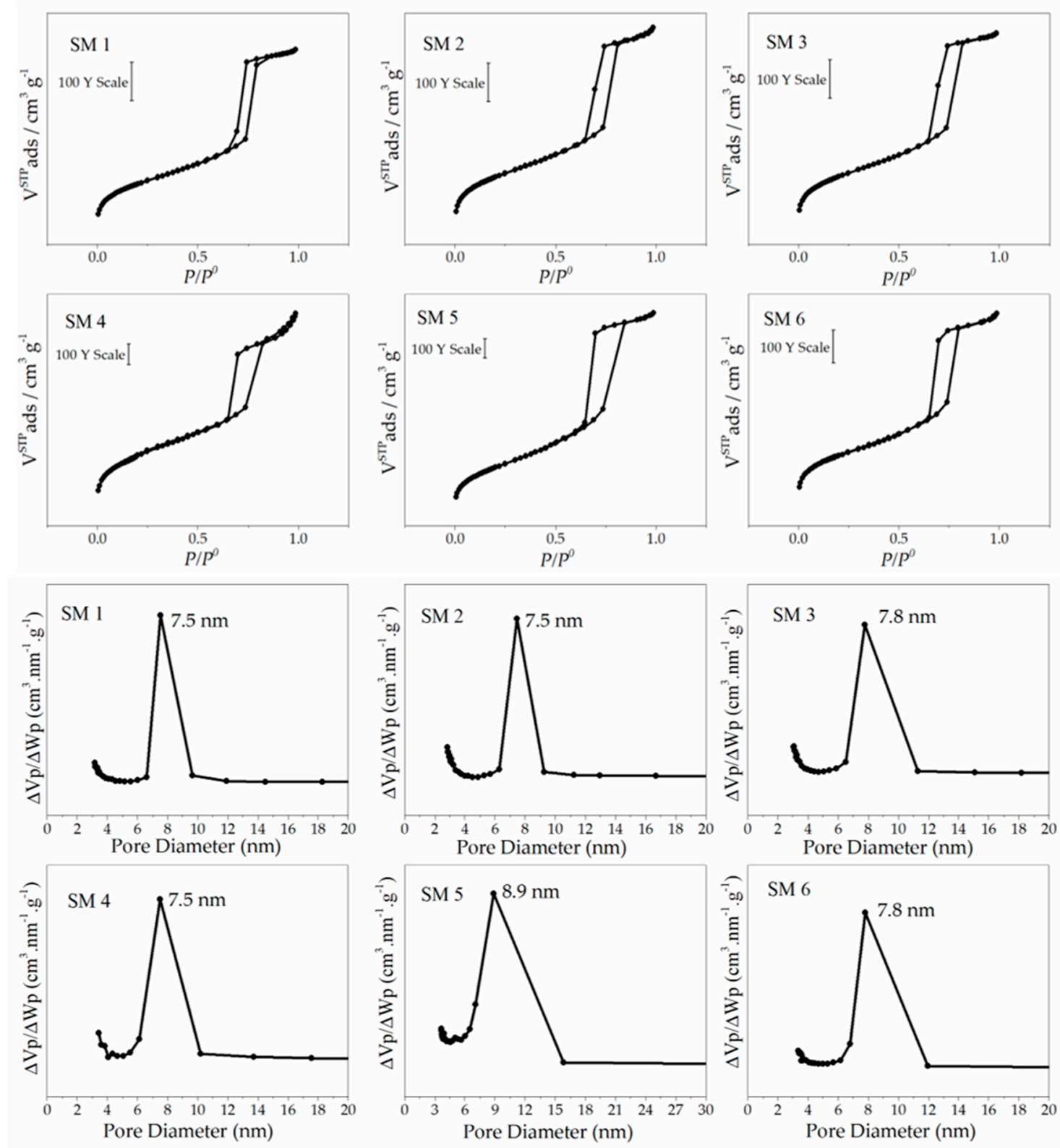

Figure 4. $\mathrm{N}_{2}$ sorption isotherm and pore distribution of SBA-15 calcined under different conditions. 

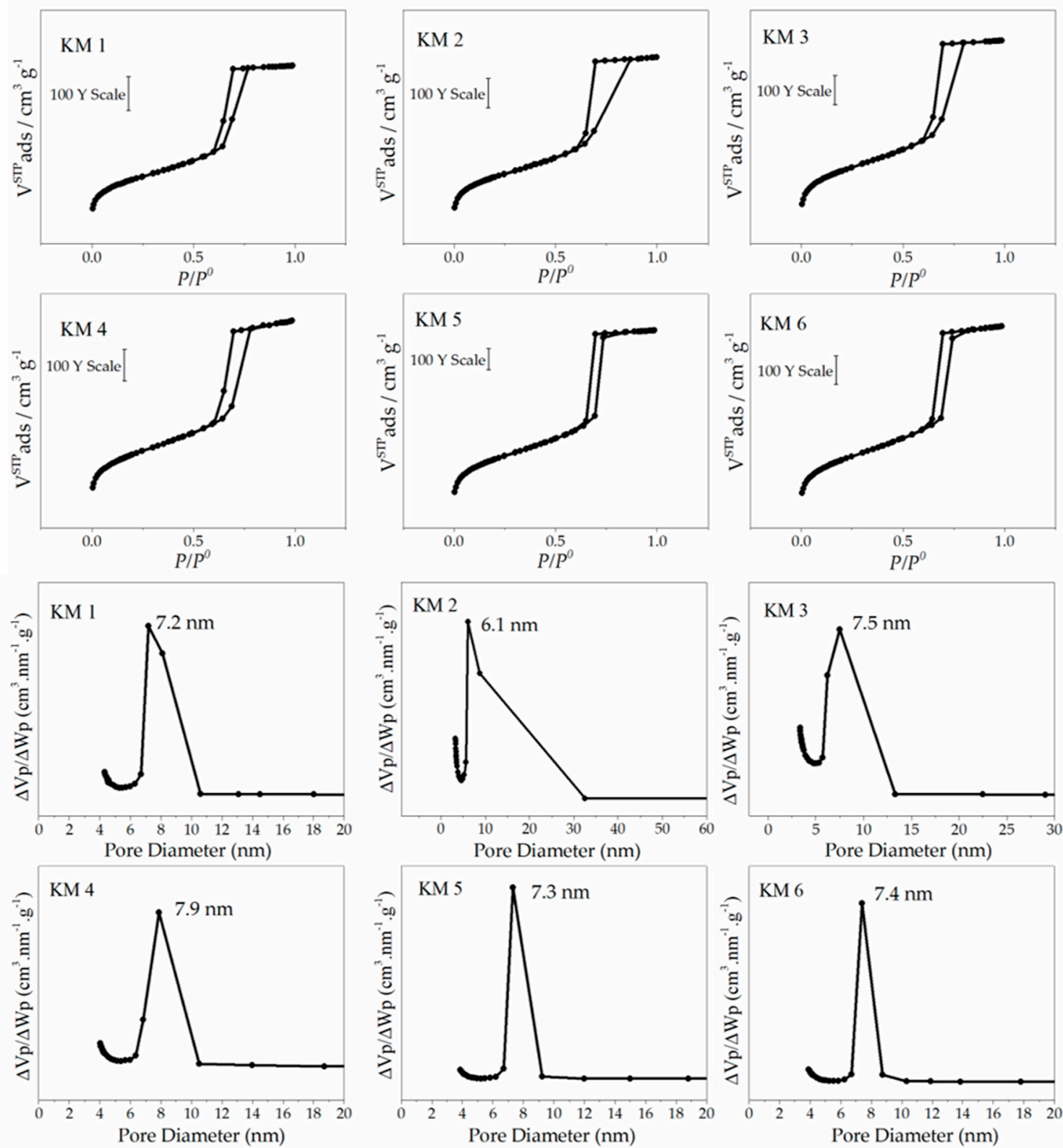

Figure 5. $\mathrm{N}_{2}$ sorption isotherm and pore distribution of KIT-6 calcined under different conditions.

The results show that, for SBA-15, the mesoporous volume and pore diameter increased as the heat treatment conditions became more drastic, ultimately reaching their maximum values upon calcination at $500{ }^{\circ} \mathrm{C}$ for $5 \mathrm{~h}$, showing that, under these conditions, dehydroxylation becomes more intense. The literature reports that calcining at temperatures above $600{ }^{\circ} \mathrm{C}$ greatly affects the textural properties of the MNS [77]. For KIT-6, the maximum mesopore volume was obtained under the calcination conditions of $500{ }^{\circ} \mathrm{C}$ for $5 \mathrm{~h}$. When the heat exposure time was doubled, a contraction of the mesoporous volume was observed, evidencing the greater tendency to dehydroxylate the material at higher temperatures. Structure shortening under the most extreme conditions was also observed in the XRD analysis. This behavior is attributed to the structure of the interconnected mesopore channels, forming cubic symmetry. This can hinder heat flow within the material, and, as the results of the elemental analysis show, the carbon content in the most extreme methodology is higher in KIT-6 than in SBA-15, showing a greater difficulty for heat flow in those materials. 


\subsection{Effect of the Calcination Temperature on the Silanol Groups}

The results of ${ }^{29} \mathrm{Si}$ solid-state CP-MAS NMR experiments are shown in Figure 6. The literature [69] reports three characteristic resonance peaks for these types of materials at $-110 \mathrm{ppm},-101 \mathrm{ppm}$, and -92 ppm, corresponding to species $\mathrm{Q}^{4}$ (siloxane, $\left.\mathrm{Si}(\mathrm{OSi})_{4}\right), \mathrm{Q}^{3}$ (vicinal silanol, $\mathrm{Si}(\mathrm{OSi})_{3}(\mathrm{OH})$ ) and $\mathrm{Q}^{2}$ (geminal silanol, $\left.\mathrm{Si}(\mathrm{OSi})_{2}(\mathrm{OH})_{2}\right)$.

Table 5 gives an overview of the meaning peaks characteristics, showing the position of the peaks, these intensities and the corresponding integration peaks of each specie, calculated in terms of percentage [78]. Figure 6 is a qualitative analysis and its results must be compared with some quantitative dates. In this manner, the Table 5 gives additional information showing that the integrations percentages areas oscillate between $13.8-16.1 \%, 69.3-73.4 \%$, and $11.6-15.1 \%$ for SBA-15 samples, respectively, in the peaks $\mathrm{Q}^{2}, \mathrm{Q}^{3}$, and $\mathrm{Q}^{4}$, considering only the calcinated samples. In the same way, for the KIT-6 samples, the integration percentage areas oscillate between $11.8-16.9 \%$, $67.8-77.3 \%$, and $10.4-16.0 \%$, respectively, in the peaks $Q^{2}, Q^{3}$, and $Q^{4}$, considering only the calcinated samples. The position of the peaks is in accordance with literature [69].

Table 5. Parameters of ${ }^{1} \mathrm{H}$ decoupled ${ }^{29}$ Si solid-state MAS NMR spectra of SBA-15 and KIT-6 samples.

\begin{tabular}{|c|c|c|c|c|}
\hline Samples & Signal & $\delta(\mathrm{ppm})$ & Intensity & Area (\%) \\
\hline \multirow{3}{*}{ SM0 } & $\mathrm{Q}^{2}$ & -91.3 & 127 & 8.0 \\
\hline & $\mathrm{Q}^{3}$ & -101.3 & 549 & 65.8 \\
\hline & $\widehat{\mathrm{Q}}^{4}$ & -110.3 & 228 & 26.2 \\
\hline \multirow{3}{*}{ SM1 } & $\mathrm{Q}^{2}$ & -91.2 & 145 & 15.9 \\
\hline & $\hat{\mathrm{Q}}^{3}$ & -100.5 & 455 & 72.5 \\
\hline & $\mathrm{Q}^{4}$ & -109.7 & 76 & 11.6 \\
\hline \multirow{3}{*}{ SM2 } & $\mathrm{Q}^{2}$ & -91.4 & 39 & 16.1 \\
\hline & $\widehat{Q}^{3}$ & -100.5 & 123 & 72.3 \\
\hline & $\widehat{\mathrm{Q}}^{4}$ & -109.0 & 25 & 11.6 \\
\hline \multirow{3}{*}{ SM3 } & $\mathrm{Q}^{2}$ & -91.6 & 662 & 13.8 \\
\hline & $\mathrm{Q}^{3}$ & -100.3 & 2227 & 73.4 \\
\hline & $\widehat{\mathrm{Q}}^{4}$ & -109.0 & 516 & 12.8 \\
\hline \multirow{3}{*}{ SM4 } & $\mathrm{Q}^{2}$ & -91.1 & 740 & 14.8 \\
\hline & $\mathrm{Q}^{3}$ & -100.2 & 2308 & 72.0 \\
\hline & $\widehat{\mathrm{Q}}^{4}$ & -108.1 & 548 & 13.2 \\
\hline \multirow{3}{*}{ SM5 } & $\mathrm{Q}^{2}$ & -91.3 & 160 & 16.0 \\
\hline & $\mathrm{Q}^{3}$ & -100.4 & 449 & 70.5 \\
\hline & $\widehat{Q}^{4}$ & -108.1 & 126 & 13.5 \\
\hline \multirow{3}{*}{ SM6 } & $\mathrm{Q}^{2}$ & -91.2 & 746 & 15.6 \\
\hline & $\mathrm{Q}^{3}$ & -100.1 & 1931 & 69.3 \\
\hline & $\mathrm{Q}^{4}$ & -109.7 & 439 & 15.1 \\
\hline \multirow{3}{*}{ KM0 } & $\mathrm{Q}^{2}$ & -91.2 & 196 & 16.9 \\
\hline & $\widehat{Q}^{3}$ & -100.8 & 605 & 67.8 \\
\hline & $\mathrm{Q}^{4}$ & -109.8 & 142 & 15.3 \\
\hline \multirow{3}{*}{ KM1 } & $\mathrm{Q}^{2}$ & -91.4 & 315 & 16.1 \\
\hline & $\mathrm{Q}^{3}$ & -100.5 & 961 & 72.2 \\
\hline & $\widehat{\mathrm{Q}}^{4}$ & -108.9 & 188 & 11.7 \\
\hline \multirow{3}{*}{ KM2 } & $\mathrm{Q}^{2}$ & -91.2 & 105 & 14.6 \\
\hline & $\mathrm{Q}^{3}$ & -100.1 & 362 & 75.0 \\
\hline & $\mathrm{Q}^{4}$ & -109.0 & 64 & 10.4 \\
\hline \multirow{3}{*}{ KM3 } & $\mathrm{Q}^{2}$ & -91.5 & 73 & 15.0 \\
\hline & $\hat{\mathrm{Q}}^{3}$ & -100.3 & 204 & 73.8 \\
\hline & $\widehat{\mathrm{Q}}^{4}$ & -109.0 & 39 & 11.2 \\
\hline
\end{tabular}


Table 5. Cont.

\begin{tabular}{ccccc}
\hline Samples & Signal & $\boldsymbol{\delta}(\mathbf{p p m})$ & Intensity & Area (\%) \\
\hline \multirow{3}{*}{ KM4 } & $\mathrm{Q}^{2}$ & -91.2 & 1103 & 11.8 \\
& $\mathrm{Q}^{3}$ & -100.7 & 3928 & 77.3 \\
& $\mathrm{Q}^{4}$ & -111.0 & 956 & 11.0 \\
\hline \multirow{3}{*}{ KM5 } & $\mathrm{Q}^{2}$ & -91.2 & 1329 & 15.8 \\
& $\mathrm{Q}^{3}$ & -100.7 & 3528 & 69.0 \\
& $\mathrm{Q}^{4}$ & -111.0 & 1086 & 15.2 \\
\hline \multirow{3}{*}{ KM6 } & $\mathrm{Q}^{2}$ & -91.6 & 113 & 14.0 \\
& $\mathrm{Q}^{3}$ & -100.3 & 295 & 69.9 \\
& $\mathrm{Q}^{4}$ & -108.7 & 76 & 16.0 \\
\hline
\end{tabular}
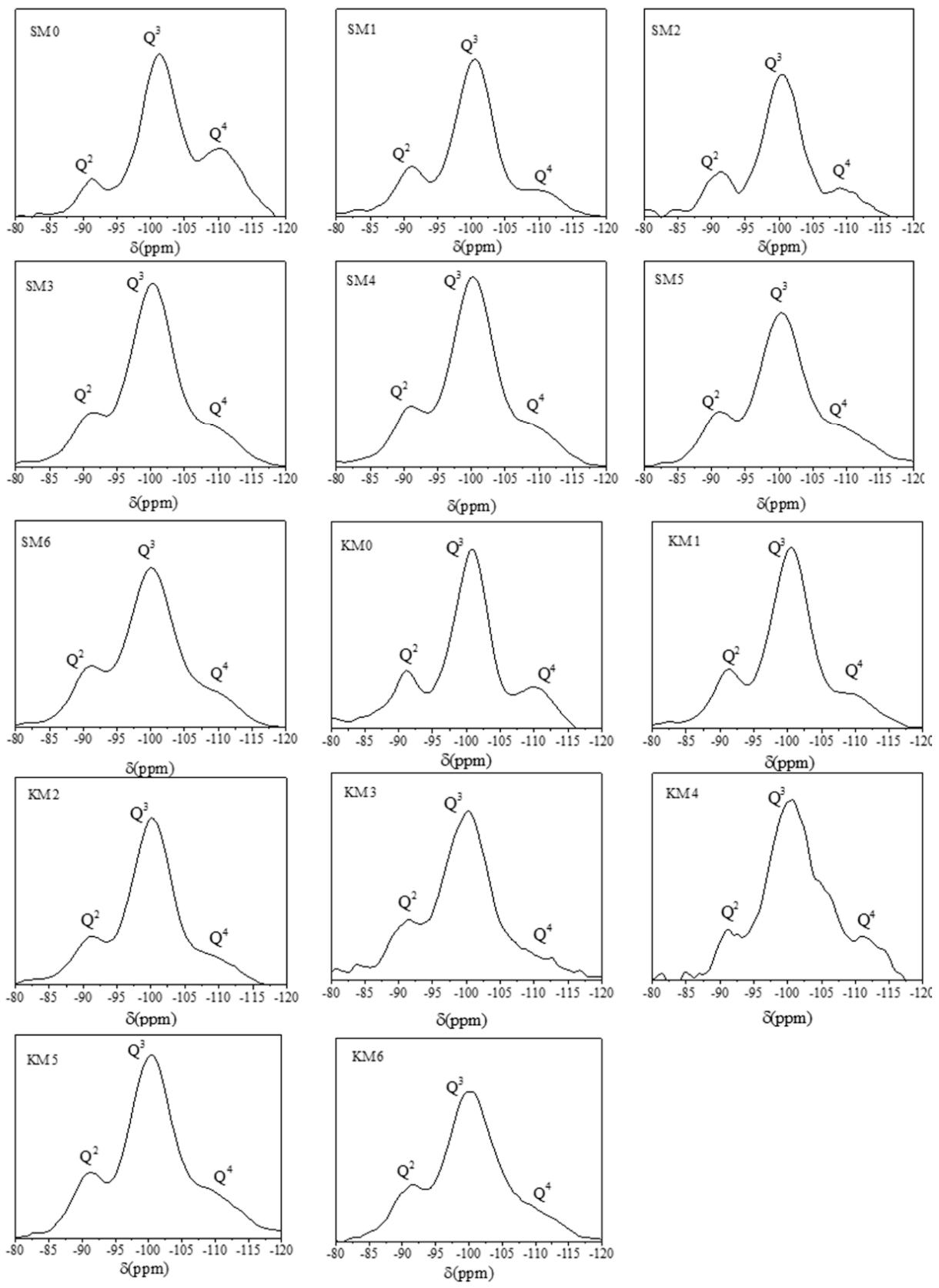

Figure 6. ${ }^{1} \mathrm{H}$ decoupled ${ }^{29} \mathrm{Si}$ solid-state magic-angle spinning (MAS) nuclear magnetic resonance (NMR) spectra of the SBA-15 and KIT-6 samples calcined under different conditions. 
The literature reports a tendency to increase the $\mathrm{Q}^{3}$ and, especially, $\mathrm{Q}^{4}$ signal, as the calcination temperature increases $[69,78]$. Molecular sieves such as SBA-15 and KIT-6 have more siloxane groups than vicinal silanols. Thus, the $\mathrm{Q}^{4}$ signal should be more intense than the $\mathrm{Q}^{3}$ signal, even in qualitative analyses. However, due to the porosity of these samples and because there is no pretreatment needed for NMR analysis, moisture retained in the pores affects the $Q^{3}$ and $Q^{4}$ signal intensities; thus, the $Q^{3}$ intensity is dominant [78]. A manner for minimizing this effect is a relative analysis the peaks. Table 6 presents the ratios of the percentage area integration of $Q^{2}: Q^{4}, Q^{3}: Q^{4}$, and $Q^{2}: Q^{3}$ just for the calcinated samples.

Table 6. Peak ratios of ${ }^{1} \mathrm{H}$ decoupled ${ }^{29} \mathrm{Si}$ solid-state MAS NMR spectra of SBA-15 and KIT-6 samples.

\begin{tabular}{cccc}
\hline Samples & $\mathbf{Q}^{\mathbf{2}}: \mathbf{Q}^{\mathbf{4}}$ & $\mathbf{Q}^{\mathbf{3}}: \mathbf{Q}^{\mathbf{4}}$ & $\mathbf{Q}^{\mathbf{2}}: \mathbf{Q}^{\mathbf{3}}$ \\
\hline SM1 & 1.37 & 6.25 & 0.22 \\
SM2 & 1.38 & 6.23 & 0.22 \\
SM3 & 1.07 & 5.73 & 0.19 \\
SM4 & 1.12 & 5.45 & 0.21 \\
SM5 & 1.19 & 5.22 & 0.23 \\
SM6 & 1.03 & 4.58 & 0.22 \\
KM1 & 1.37 & 6.17 & 0.22 \\
KM2 & 1.40 & 7.21 & 0.19 \\
KM3 & 1.33 & 6.59 & 0.20 \\
KM4 & 1.07 & 7.03 & 0.15 \\
KM5 & 1.03 & 4.54 & 0.23 \\
KM6 & 0.88 & 4.37 & 0.20 \\
\hline
\end{tabular}

According to results presented in the Table 6 for SBA-15 and KIT-6, the ratio $Q^{2}: Q^{4}$ decreases as the temperature increases, indicating that the geminal silanols are converted in siloxane as the temperature increases. Besides that, in $400{ }^{\circ} \mathrm{C}$, the most accentuated decrease in this ratio begins, indicating that the dehydroxylation had started and that this is the crucial moment for preserving the geminal silanols. This is in accordance with the results obtained from $\mathrm{N}_{2}$ sorption and XRD because silanol condensation shrinks the structure and decreases the total pore volume. This result indicates that calcination at $300^{\circ} \mathrm{C}$ is more beneficial than that at $400^{\circ} \mathrm{C}$ in terms of silanol preservation. Nonetheless, the $\mathrm{N}_{2}$ sorption results show that the pore volume is small upon calcination at $300{ }^{\circ} \mathrm{C}$. The ratio $\mathrm{Q}^{3}: \mathrm{Q}^{4}$ decreases too as the temperature increases; however, it is most accentuated at the most extreme treatment $\left(500{ }^{\circ} \mathrm{C}\right.$ during $\left.10 \mathrm{~h}\right)$. In this way, this result indicates a tendency to convert the vicinal silanol in siloxane, as expected. The ratio $Q^{2}: Q^{3}$ is practically unchanged.

\section{Conclusions}

The calcination of mesoporous SBA- 15 and KIT- 6 at $300{ }^{\circ} \mathrm{C}$ for $5 \mathrm{~h}$ eliminates almost all the polymer and produces compounds with good structural properties. However, to optimize the textural properties of these materials, such as pore area and pore volume, a calcination at $400{ }^{\circ} \mathrm{C}$ for $10 \mathrm{~h}$ or at $500^{\circ} \mathrm{C}$ for $5 \mathrm{~h}$ is the best condition for SBA-15, while for KIT-6, the best performance is obtained upon calcining at $500^{\circ} \mathrm{C}$ for $5 \mathrm{~h}$.

The deterioration of the silanol groups by condensation becomes more relevant at temperatures above $400{ }^{\circ} \mathrm{C}$. The results show that geminal silanols are better preserved. Therefore, for the surface modification of SBA-15 and KIT-6 via their hydroxyl groups, it is preferable to calcine at $300{ }^{\circ} \mathrm{C}$ for $5 \mathrm{~h}$ or, at the most, at $400{ }^{\circ} \mathrm{C}$ for $5 \mathrm{~h}$. Although there is a decrease in the pore area and volume, hydroxylated silica groups will be more abundant.

Although most mesoporous synthesis involves calcining for $5 \mathrm{~h}$ at $600{ }^{\circ} \mathrm{C}$, to the best of our knowledge, this method is unnecessary, resulting in a waste of time and silanol groups without compensatory benefits to justify this method. 
Author Contributions: “A.M.B and S.B.C.P. conceived and designed the experiments; A M.B. and B.P.N. performed the experiments; A.M.B. and K.B.-G. analyzed the data; S.B.C.P. contributed reagents/materials/analysis tools; A.M.B. and B.P.N wrote the paper; S.B.C.P. and K.B.-G. corrected the paper". All authors have read and agreed to the published version of the manuscript.

Funding: This research was funded by CAPES, Finance Code 001.

Acknowledgments: All the authors are grateful for support from LABPEMOL and LRC Brazilian laboratories groups, situated, respectively, in the cities of Natal/RN and Porto Alegre/RS.

Conflicts of Interest: The authors declare no conflict of interest. The funders had no role in the design of the study; in the collection, analysis, or interpretation of data; in the writing of the manuscript; or in the decision to publish the results.

\section{References}

1. Guillet-Nicolas, R.; Ahmad, R.; Cychosz, K.A.; Kleitz, F.; Thommes, M. Insights into the pore structure of KIT- 6 and SBA-15 ordered mesoporous silica-Recent advances by combining physical adsorption with mercury porosimetry. New J. Chem. 2016, 40, 4351-4360. [CrossRef]

2. Hoffmann, F.; Cornelius, M.; Morell, J.; Fröba, M. Silica-Based mesoporous organic-inorganic hybrid materials. Angew. Chem. Int. Ed. 2006, 45, 3216-3251. [CrossRef] [PubMed]

3. Kresge, C.T.; Leonowicz, M.E.; Roth, W.J.; Vartuli, J.C.; Beck, J.S. Ordered mesoporous molecular sieves synthesized by a liquid-crystal template mechanism. Nature 1992, 359, 710-712. [CrossRef]

4. Beck, J.S.; Vartuli, J.C.; Roth, W.J.; Leonowicz, M.E.; Kresge, C.T.; Schmitt, K.D.; Chu, C.T.W.; Olson, D.H.; Sheppard, E.W.; McCullen, S.B.; et al. A new family of mesoporous molecular sieves prepared with liquid crystal templates. J. Am. Chem. Soc. 1992, 114, 10834-10843. [CrossRef]

5. Kishor, R.; Ghoshal, A.K. Understanding the hydrothermal, thermal, mechanical and hydrolytic stability of mesoporous KIT-6: A comprehensive study. Microporous Mesoporous Mater. 2017, 242, 127-135. [CrossRef]

6. Chen, C.Y.; Burkett, S.L.; Li, H.X.; Davis, M.E. Studies on mesoporous materials II. Synthesis mechanism of MCM-41. Microporous Mater. 1993, 2, 27-34. [CrossRef]

7. Chen, C.Y.; Li, H.X.; Davis, M.E. Studies on mesoporous materials I: Synthesis and characterization of MCM-41. Microporous Mater. 1993, 2, 17-26. [CrossRef]

8. Corma, A. From microporous to mesoporous molecular sieve materials and their use in catalysis. Chem. Rev. 1997, 97, 2373-2420. [CrossRef]

9. Kruk, M.; Jaroniec, M.; Ryoo, R.; Kim, J.M. Characterization of high-quality MCM-48 and SBA-1 mesoporous silicas. Chem. Mater. 1999, 119, 2568-2572. [CrossRef]

10. Soler Illia, G.J.A.A.; Crepaldi, E.L.; Grosso, D.; Sanchez, C. Block copolymer-templated mesoporous oxides. Curr. Opin. Colloid Interface Sci. 2003, 8, 109-126. [CrossRef]

11. Meynen, V.; Cool, P.; Vansant, E.F. Verified syntheses of mesoporous materials. Microporous Mesoporous Mater. 2009, 125, 170-223. [CrossRef]

12. Yang, Z.; Lu, Y.; Yang, Z. Mesoporous materials: Tunable structure, morphology and composition. Chem. Commun. 2009, 2270-2277. [CrossRef] [PubMed]

13. Zhao, D.; Feng, J.; Huo, Q.; Melosh, N.; Fredrickson, G.H.; Chmelka, B.F.; Stucky, G.D. Triblock copolymer syntheses of mesoporous silica with periodic 50 to 300 angstrom pores. Science 1998, 279, 548-552. [CrossRef] [PubMed]

14. Zhao, D.; Huo, Q.; Feng, J.; Chmelka, B.F.; Stucky, G.D. Nonionic triblock and star diblock copolymer and oligomeric surfactant syntheses of highly ordered, hydrothermally stable, mesoporous silica structures. J. Am. Chem. Soc. 1998, 120, 6024-6036. [CrossRef]

15. Kleitz, F.; Choi, S.H.; Ryoo, R. Cubic Ia3d large mesoporous silica: Synthesis and replication to platinum nanowires, carbon nanorods and carbon nanotubes. Chem. Commun. 2003, 7, 2136-2137. [CrossRef]

16. Guo, W.; Kleitz, F.; Cho, K.; Ryoo, R. Large pore phenylene-bridged mesoporous organosilica with bicontinuous cubic Ia3d (KIT-6) mesostructure. J. Mater. Chem. 2010, 20, 8257. [CrossRef]

17. Boulaoued, A.; Fechete, I.; Donnio, B.; Bernard, M.; Turek, P.; Garin, F. Microporous and mesoporous materials Mo/KIT-6, Fe/KIT-6 and Mo-Fe/KIT-6 as new types of heterogeneous catalysts for the conversion of MCP. Microporous Mesoporous Mater. 2012, 155, 131-142. [CrossRef] 
18. Sakamoto, Y.; Kim, T.W.; Ryoo, R.; Terasaki, O. Three-Dimensional structure of large-pore mesoporous cubic Ia3d silica with complementary pores and its carbon replica by electron crystallography. Angew. Chem. Int. Ed. 2004, 43, 5231-5234. [CrossRef]

19. Qian, L.; Ren, Y.; Liu, T.; Pan, D.; Wang, H.; Chen, G. Influence of KIT-6' s pore structure on its surface properties evaluated by inverse gas chromatography. Chem. Eng. J. 2012, 213, 186-194. [CrossRef]

20. Arribas, M.A.; Prieto, G. Cobalt supported on morphologically tailored SBA-15 mesostructures: The impact of pore length on metal dispersion and catalytic activity in the Fischer-Tropsch synthesis. Appl. Catal. A Gen. 2009, 367, 146-156. [CrossRef]

21. Mohammadzadeh, M.; Nourbakhsh, M.S.; Khodaverdi, E.; Hadizadeh, F.; Omid Malayeri, S. Enhanced loading and release of non-steroidal anti-inflammatory drugs from silica-based nanoparticle carriers. Chem. Biol. Drug Des. 2016, 88, 370-379. [CrossRef]

22. Janković-Tomanić, M.; Todorovic, D.; Stanivukovic, Z.; Peric Mataruga, V.; Wessjohann, L.; Kaludjerovic, G. Mesoporous silica nanoparticles SBA-15 loaded with emodin upregulate the antioxidative defense of Euproctis chrysorrhoea (L.) larvae. Turk. J. Biol. 2017, 41, 935-942. [CrossRef]

23. Chaudhari, S.; Gupte, A. Mesoporous silica as a carrier for amorphous solid dispersion. Br. J. Pharm. Res. 2017, 16, 1-19. [CrossRef]

24. Varghese, J.; Sakthipriya, P.; Rachel, G.; Ananthi, N. Polylactic acid coated SBA-15 functionalized with 3-aminopropyl triethoxysilane. Indian J. Chem. Sect. A Inorg. Phys. Theor. Anal. Chem. 2017, 56A, $621-625$. Available online: http://nopr.niscair.res.in/handle/123456789/42313 (accessed on 26 November 2019).

25. Huang, W.; Zhang, Y.; Li, D. Adsorptive removal of phosphate from water using mesoporous materials: A review. J. Environ. Manag. 2017, 193, 470-482. [CrossRef]

26. Jahandar Lashaki, M.; Sayari, A. $\mathrm{CO}_{2}$ capture using triamine-grafted SBA-15: The impact of the support pore structure. Chem. Eng. J. 2018, 334, 1260-1269. [CrossRef]

27. Pathan, S.; Solanki, P.; Patel, A. Functionalized SBA-15 for controlled release of poorly soluble drug, Erythromycin. Microporous Mesoporous Mater. 2018, 258, 114-121. [CrossRef]

28. Szewczyk, A.; Prokopowicz, M.; Sawicki, W.; Majda, D.; Walker, G. Aminopropyl-Functionalized mesoporous silica SBA-15 as drug carrier for cefazolin: Adsorption profiles, release studies, and mineralization potential. Microporous Mesoporous Mater. 2019, 274, 113-126. [CrossRef]

29. Yan, Z.; Ikram, M.; Ullah, R.; Zeng, J.; Subhan, F.; Aslam, S.; Rehman, S.; Xing, W.; Liu, Y. Rapid functionalization of as-synthesized KIT-6 with nickel species occluded with template for adsorptive desulfurization. Microporous Mesoporous Mater. 2015, 214, 54-63. [CrossRef]

30. Zeng, J.; Ahmad, A.; Naeem, M.; Aslam, S.; Subhan, F.; Ullah, R.; Zhen, L.; Yan, Z.; Etim, U.J. Facile functionalization of 3-D ordered KIT-6 with cuprous oxide for deep desulfurization. Chem. Eng. J. 2017, 330, 372-382. [CrossRef]

31. Saadati-Moshtaghin, H.R.; Zonoz, F.M.; Amini, M.M. Synthesis and characterization of ZnO incorporated magnetically recoverable KIT-6 as a novel and efficient catalyst in the preparation of symmetrical N,N'-alkylidene bisamides. J. Solid State Chem. 2018, 260, 16-22. [CrossRef]

32. Taghizadeh, M.; Akhoundzadeh, H.; Rezayan, A.; Sadeghian, M. Excellent catalytic performance of 3D-mesoporous KIT-6 supported $\mathrm{Cu}$ and Ce nanoparticles in methanol steam reforming. Int. J. Hydrog. Energy 2018, 43, 10926-10937. [CrossRef]

33. Lv, Y.; Xin, Z.; Meng, X.; Tao, M.; Bian, Z.; Gu, J.; Gao, W. Essential role of organic additives in preparation of efficient Ni/KIT-6 catalysts for CO methanation. Appl. Catal. A Gen. 2018, 558, 99-108. [CrossRef]

34. Mahdizadeh Ghohe, N.; Tayebee, R.; Amini, M.M. Synthesis and characterization of mesoporous Nb-Zr/KIT-6 as a productive catalyst for the synthesis of benzylpyrazolyl coumarins. Mater. Chem. Phys. 2019, 223, 268-276. [CrossRef]

35. Cho, J.M.; Kasipandi, S.; Park, Y.M.; Bae, J.W. Spatially confined cobalt nanoparticles on zirconium phosphate-modified KIT-6 for an enhanced stability of CO hydrogenation to hydrocarbons. Fuel 2019, 239, 547-558. [CrossRef] 
36. Swirk, K.; Galvez, M.E.; Motak, M.; Grzybek, T.; Rønning, M.; Da Costa, P. Syngas production from dry methane reforming over yttrium-promoted nickel-KIT-6 catalysts. Int. J. Hydrog. Energy 2019, 44, 274-286. [CrossRef]

37. Naidu, S.; Ramadass, K.; Ruban, S.J.; Benzigar, M. 3D cubic mesoporous $\mathrm{C}_{3} \mathrm{~N}_{4}$ with tunable pore diameters derived from KIT-6 and their application in base catalyzed Knoevenagel reaction. Catal. Today 2019, 324, 33-38. [CrossRef]

38. Bao, B.Q.; Le, N.H.; Nguyen, D.H.T.; Tran, T.V.; Pham, L.P.T.; Bach, L.G.; Ho, H.M.; Nguyen, T.H.; Nguyen, D.H. Evolution and present scenario of multifunctionalized mesoporous nanosilica platform: A mini review. Mater. Sci. Eng. C 2018, 91, 912-928. [CrossRef]

39. Rosenholm, J.M.; Sahlgren, C.; Lindén, M. Towards multifunctional, targeted drug delivery systems using mesoporous silica nanoparticles-Opportunities \& challenges. Nanoscale 2010, 2, 1870-1883. [CrossRef]

40. Tang, F.; Li, L.; Chen, D. Mesoporous silica nanoparticles: Synthesis, biocompatibility and drug delivery. Adv. Mater. 2012, 24, 1504-1534. [CrossRef]

41. Alothman, Z.A.; Apblett, A.W. Metal ion adsorption using polyamine-functionalized mesoporous materials prepared from bromopropyl-functionalized mesoporous silica. J. Hazard. Mater. 2010, 182, 581-590. [CrossRef]

42. Alothman, Z.A.; Apblett, A.W. Preparation of mesoporous silica with grafted chelating agents for uptake of metal ions. Chem. Eng. J. 2009, 155, 916-924. [CrossRef]

43. Alothman, Z.A.; Apblett, A.W. Synthesis and characterization of a hexagonal mesoporous silica with enhanced thermal and hydrothermal stabilities. Appl. Surf. Sci. 2010, 256, 3573-3580. [CrossRef]

44. Brinker, C.J.; Scherer, G. Sol-Gel Science: The Physics and Chemistry of Sol-Gel Processing, 1st ed.; Academic Press Inc.: New York, NY, USA, 1990.

45. Alothman, Z.A. A review: Fundamental aspects of silicate mesoporous materials. Materials 2012, 5, $2874-2902$. [CrossRef]

46. Esposito, S. "Traditional" sol-gel chemistry as a powerful tool for the preparation of supported metal and metal oxide catalysts. Materials 2019, 12, 668. [CrossRef] [PubMed]

47. Danks, A.E.; Hallb, S.R.; Schnepp, Z. The evolution of 'sol-gel' chemistry as a technique for materials synthesis. Mater. Horiz. 2016, 3, 91-112. [CrossRef]

48. Esposito, S.; Sannino, F.; Pansini, M.; Bonelli, B.; Garrone, E. Modes of interaction of simazine with the surface of model amorphous silicas in water. J. Phys. Chem. C 2013, 117, 11203-11210. [CrossRef]

49. Esposito, S.; Sannino, F.; Pansini, M.; Bonelli, B.; Garrone, E. Modes of interaction of simazine with the surface of amorphous silica in water. Part II: Adsorption at temperatures higher than ambient. J. Phys. Chem. C 2013, 117, 27047-27051. [CrossRef]

50. Al-Atia, M.H.J.H.; Saeed, H.K.; Fliayh, A.R.; Addie, A.J. Investigating the effects of calcination temperatures on the structure of modified nanosilica prepared by sol-gel. Colloids Surf. A Physicochem. Eng. Asp. 2017, 520, 590-596. [CrossRef]

51. Ojeda-López, R.; Hermosillo, I.J.P.; Esparza-Schulz, J.M.; Domínguez, A. Efecto de la temperatura de calcinación sobre la concentración de grupos silanoles en superficies de $\mathrm{SiO}_{2}$ (SBA-15). Av. Quím. 2014, 9, 21-28. Available online: http://www.redalyc.org/articulo.oa?id=93330767007 (accessed on 28 July 2019).

52. Van Der Voort, P.; Gillis-D'Hamers, I.; Vrancken, K.C.; Vansant, E.F. Effect of porosity on the distribution and reactivity of hydroxyl groups on the surface of silica gel. J. Chem. Soc. Faraday Trans. 1991, 87, 3899-3905. [CrossRef]

53. Chen, S.Y.; Tang, C.Y.; Lee, J.F.; Jang, L.Y.; Tatsumi, T.; Cheng, S. Effect of calcination on the structure and catalytic activities of titanium incorporated SBA-15. J. Mater. Chem. 2011, 21, 2255-2265. [CrossRef]

54. Li, C.Y.; Qi, N.; Liu, Z.W.; Zhou, B.; Chen, Z.Q.; Wang, Z. Effect of synthesis temperature on the ordered pore structure in mesoporous silica studied by positron annihilation spectroscopy. Appl. Surf. Sci. 2016, 363, 445-450. [CrossRef]

55. Mariano-Neto, F.; Cides, L.C.; Oliveira, C.L.P.; Fantini, M.C.A. Vacuum calcination behavior of SBA-15 ordered mesoporous silica. Braz. J. Phys. 2018, 48, 442-450. [CrossRef]

56. Wang, X.; Lin, K.S.K.; Chan, J.C.C.; Cheng, S. Direct synthesis and catalytic applications of ordered large pore aminopropyl-functionalized SBA-15 mesoporous materials. J. Phys. Chem. B 2005, 109, 1763-1769. [CrossRef] 
57. Rossetto, E.; Nicola, B.P.; De Souza, R.F.; Pergher, S.B.C.; Bernardo-Gusmão, K. Anchoring via covalent binding of $\beta$-diimine-nickel complexes in SBA-15 and its application in catalytic reactions. Appl. Catal. A Gen. 2015, 502, 221-229. [CrossRef]

58. Rossetto, E. Heterogenized Nickel- $\beta$-Diimines Complexes in MCM-41 and SBA-15: Application in Olefin Oligomerization. Ph.D. Thesis, Federal University of Rio Grande do Norte, Natal, Brazil, 2015. Available online: https://repositorio.ufrn.br/jspui/bitstream/123456789/20557/1/EnedersonRossetto_TESE.pdf (accessed on 27 November 2019).

59. Sayed, E.; Haj-Ahmad, R.; Ruparelia, K.; Arshad, M.S.; Chang, M.-W.; Ahmad, Z. Porous inorganic drug delivery systems-A review. AAPS PharmSciTech 2017, 18, 1507-1525. [CrossRef]

60. Vallet-Regí, M.; Colilla, M.; Izquierdo-Barba, I.; Manzano, M. Mesoporous silica nanoparticles for drug delivery: Current insights. Molecules 2017, 23, 47. [CrossRef]

61. Falahati, M.; Ma'mani, L.; Saboury, A.A.; Shafiee, A.; Foroumadi, A.; Badiei, A.R. Aminopropyl-Functionalized cubic Ia3d mesoporous silica nanoparticle as an efficient support for immobilization of superoxide dismutase. Biochim. Biophys. Acta Proteins Proteom. 2011, 1814, 1195-1202. [CrossRef]

62. Kalbasi, R.J.; Mosaddegh, N. Pd-poly(N-vinyl-2-pyrrolidone)/KIT-6 nanocomposite: Preparation, structural study, and catalytic activity. C. R. Chim. 2012, 15, 988-995. [CrossRef]

63. Lee, A.F.; Pirez, C.; Wilson, K.; Caderon, J.-M.; Dacquin, J.-P. Tunable KIT-6 mesoporous sulfonic acid catalysts for fatty acid esterification. ACS Catal. 2012, 2, 1607-1614. [CrossRef]

64. Shafiee, A.; Ma'mani, L.; Saboury, A.A.; Rafieepour, H.A.; Falahati, M. The effect of functionalization of mesoporous silica nanoparticles on the interaction and stability of confined enzyme. Int. J. Biol. Macromol. 2012, 50, 1048-1054. [CrossRef]

65. Valle-Vigón, P.; Sevilla, M.; Fuertes, A.B. Functionalization of mesostructured silica-carbon composites. Mater. Chem. Phys. 2013, 139, 281-289. [CrossRef]

66. Visuvamithiran, P.; Palanichamy, M.; Shanthi, K.; Murugesan, V. Selective epoxidation of olefins over Co(II)-Schiff base immobilised on KIT-6. Appl. Catal. A Gen. 2013, 462-463, 31-38. [CrossRef]

67. Xu, L.; Wang, C.; Guan, J. Preparation of acid-base bifunctional mesoporous KIT-6 (KIT: Korea Advanced Institute of Science and Technology) and its catalytic performance in Knoevenagel reaction. J. Solid State Chem. 2014, 213, 250-255. [CrossRef]

68. Tran, T.T.V.; Kongparakul, S.; Karnjanakom, S.; Reubroycharoen, P.; Guan, G.; Chanlek, N.; Samart, C. Highly productive xylose dehydration using a sulfonic acid functionalized KIT-6 catalyst. Fuel 2019, 236, 1156-1163. [CrossRef]

69. Benamor, T.; Michelin, L.; Lebeau, B.; Marichal, C. Flash induction calcination: A powerful tool for total template removal and fine tuning of the hydrophobic/hydrophilic balance in SBA-15 type silica mesoporous materials. Microporous Mesoporous Mater. 2012, 147, 334-342. [CrossRef]

70. Serrano, D.P.; Aguado, J.; Vargas, C. A comparison of methods for the heterogenization of the chiral Jacobsen catalyst on mesostructured SBA-15 supports. Appl. Catal. A Gen. 2008, 335, 172-179. [CrossRef]

71. Li, G.; Zhao, X.S. Characterization and photocatalytic properties of titanium-containing mesoporous SBA-15. Ind. Eng. Chem. Res. 2006, 45, 3569-3573. [CrossRef]

72. Zhu, Y.; Li, H.; Xu, J.; Yuan, H.; Wang, J.; Li, X. Monodispersed mesoporous SBA-15 with novel morphologies: Controllable synthesis and morphology dependence of humidity sensing. CrystEngComm 2011, 13, 402-405. [CrossRef]

73. Wang, W.; Qi, R.; Shan, W.; Wang, X.; Jia, Q.; Zhao, J.; Zang, C.; Ru, H. Synthesis of KIT-6 type mesoporous silicas with tunable pore sizes, wall thickness and particle sizes via the partitioned cooperative self-assembly process. Microporous Mesoporous Mater. 2014, 194, 167-173. [CrossRef]

74. Thommes, M.; Kaneko, K.; Neimark, A.V.; Olivier, J.P.; Rodriguez-Reinoso, F.; Rouquerol, J.; Sing, K.S.W. Physisorption of gases, with special reference to the evaluation of surface area and pore size distribution (IUPAC Technical Report). Pure Appl. Chem. 2015, 87, 1051-1069. [CrossRef]

75. Galarneau, A.; Cambon, H.; Di Renzo, F.; Ryoo, R.; Choi, M.; Fajula, F. Microporosity and connections between pores in SBA-15 mesostructured silicas as a function of the temperature of synthesis. New J. Chem. 2003, 27, 73-79. [CrossRef]

76. Rocha, J.V.; Barrera, D.; Sapag, K. Distribución de tamaño de poros de materiales mesoporos ordenados de sílice con poros de geometría cilíndrica utilizando el método macroscópico VBS. Mater. Adsorción Catál. 2014, 7,5-14. Available online: https://ri.conicet.gov.ar/handle/11336/32159 (accessed on 18 October 2019). 
77. Ren, Y.; Jiao, F.; Bruce, P.G. Tailoring the pore size/wall thickness of mesoporous transition metal oxides. Microporous Mesoporous Mater. 2009, 121, 90-94. [CrossRef]

78. Van Der Meer, J.; Bardez-Giboire, I.; Mercier, C.; Revel, B.; Davidson, A.; Denoyel, R. Mechanism of metal oxide nanoparticle loading in SBA-15 by the double solvent technique. J. Phys. Chem. C 2010, 114, 3507-3515. [CrossRef] 